\title{
Guitartia tridentata n. gen., n. sp. (Monhysterida: Xyalidae) and Macrodontium gaspari n. gen., n. sp. (Chromadorida: Microlaimidae), free-living marine nematodes from the Caribbean Sea
}

\author{
Maickel Armenteros ${ }^{1,2, *}$, Magda VinCX ${ }^{2}$ and Wilfrida DeCraemer ${ }^{3,4}$ \\ ${ }^{1}$ Centro de Investigaciones Marinas, Universidad de La Habana. 16 \# 114, CP 11300, Playa, Ciudad Habana, Cuba \\ ${ }^{2}$ Marine Biology Section, Department of Biology, Ghent University, Krijgslaan 281 S8, 9000 Ghent, Belgium \\ ${ }^{3}$ Department of Invertebrates, Royal Belgian Institute of Natural Sciences, Vautierstraat 29, 1000 Brussels, Belgium \\ ${ }^{4}$ Nematology Section, Department of Biology, Ghent University, Ledeganckstraat 35, 9000 Ghent, Belgium
}

Received: 24 March 2009; revised: 12 October 2009

Accepted for publication: 13 October 2009

\begin{abstract}
Summary - Two new genera of free-living marine nematodes are described from the muddy bottom of Cienfuegos Bay, Caribbean Sea. Guitartia n. gen. (Xyalidae, Monhysterida) is characterised by three long tooth-like structures in the stegostom, second and third circle of anterior sensilla separate and posterior genital branch of the female restricted to a long post-vulvar sac. The type species is Guitartia tridentata n. gen., n. sp. Within the Xyalidae, Guitartia n. gen. is morphologically close to Amphimonhystrella, Cobbia, Elzalia, Scaptrella and Valvaelaimus, all being characterised by sclerotised structures in the stoma and transverse striation of the body cuticle. Main features for discrimination are the type of stoma structure, the shape and relative size of amphidial fovea, the presence of a post-vulvar sac and gubernacular apophyses and the absence of terminal setae on the tail. Macrodontium $\mathrm{n}$. gen. (Microlaimidae, Chromadorida) is characterised by a heavily sclerotised stoma with one large dorsal tooth and two smaller subventral teeth, sexual dimorphism in size and position of the amphidial fovea and males with a single anterior testis. The type species is Macrodontium gaspari n. gen., n. sp. Within the Microlaimidae, Macrodontium n. gen. is similar to the genera Acanthomicrolaimus and Bolbolaimus due to sclerotised stoma and presence of large dorsal tooth. The new genus is similar to Aponema in sexual dimorphism in the size of the amphidial fovea, monorchic males, presence of a gubernacular apophysis and conico-cylindrical tail shape. Morphological characters of diagnostic value within the family are the ornamentation of the body cuticle, relative length of cephalic sensilla, stoma sclerotisation and number of testes.
\end{abstract}

Keywords - description, morphology, morphometrics, new genus, new species, taxonomy.

Documenting the biodiversity of free-living marine nematodes is a challenging task because of high diversity the inherent difficulty of the group (i.e., small size) and various taxonomic impediments. Even with relatively modern approaches to the identification of species (barcoding, developmental biology, video vouchering), the classical morphological approach remains the first comprehensive step for recording, describing and classification. In the present study, we use the morphological species concept for delimiting species and propose two new species belonging to two new genera.

The marine nematofauna from coastal areas has been extensively studied in temperate regions, but less effort has been devoted to tropical areas. Since 2005 we have been studying the free-living marine nematodes from a tropical semi-enclosed bay in the Caribbean Sea with the aim of describing ecological patterns and carrying out taxonomic research. We detected relatively few species of nematodes (79) in Cienfuegos Bay, most of them belonging to the order Monhysterida due to the dominance of fine, muddy, sediments in the basin. Two genera of freeliving marine nematodes from this bay have been reported as new for science (Cienfuegia Armenteros, Vincx \& Decraemer, 2009 and Pseudoterschellingia Armenteros, Vincx \& Decraemer, 2009). In this article we present the description of two new genera belonging to the families Xyalidae Chitwood, 1951 and Microlaimidae Micoletzky, 1922a.

*Corresponding author, e-mail: maikel@cim.uh.cu 
The family Xyalidae Chitwood, 1951 appears to be monophyletic after Meldal et al. (2007) and within-family relationships have been revised, according to cladistic principles based on morphological and morphometric features, by Nicholas and Trueman (2002). According to these authors, the family is characterised by an annulated cuticle, six outer labial setae plus four cephalic setae arranged in one circle, and female with a single, outstretched, anterior ovary. From our results, an emended diagnosis of the family is proposed. In their analysis, Nicholas and Trueman (2002) recognised 33 genera within the family. Other genera have been included in the meantime: Arabanema Turpeenniemi, Nasira \& Maqbool, 2001; Cienfuegia; Dactylaimoides Blome, 2002; Enchonema Bussau, 1993; Manganonema Bussau, 1993; Marisalbinema Tchesunov, 1990; Paragonionchus Blome, 2002; Paramphimonhystrella Huang \& Zhang, 2006; Parelzalia Tchesunov, 1990; Pseudechinotheristus Blome, 2002; and Sacrimarinema Shoshin, 2001.

The family Microlaimidae Micoletzky, 1922a also appears to be monophyletic according to Meldal et al. (2007). The presence of a 12-fold vestibulum in stoma, teeth in the stegostom and outstretched ovaries are holapomorphies of the family (Lorenzen, 1994). A revision of the Microlaimidae was done by Jensen (1978), who proposed the erection of a new family (Molgolaimidae Jensen, 1978) and the subdivision of Microlaimidae into two subfamilies (Bolbolaiminae Jensen, 1978 and Microlaiminae Micoletzky, 1922a). Further arguments by Lorenzen (1994) suggest an absence of support for Jensen's classification and we, therefore, follow Lorenzen's classification concerning the Microlaimidae. After Lorenzen (1994) the family Microlaimidae contains seven valid genera: Aponema Jensen, 1978; Bolbolaimus Cobb, 1920; Calomicrolaimus Lorenzen, 1976; Cinctonema Cobb, 1920; Crassolaimus Kreis, 1929; Ixonema Lorenzen, 1971; and Microlaimus de Man, 1880; and one doubtful genus, Ungulilaimella Allgén, 1958. Another four valid genera have been proposed: Acanthomicrolaimus Stewart \& Nicholas, 1987; Bathynox Bussau \& Vopel, 1999; Caligocanna Bussau \& Vopel, 1999; and Spirobolbolaimus Soetaert \& Vincx, 1988.

\section{Materials and methods}

Samples were taken in subtidal stations from Cienfuegos Bay, Caribbean Sea $\left(22^{\circ} 07^{\prime} \mathrm{N}, 80^{\circ} 22^{\prime} \mathrm{W}\right)$ in February, May and September 2006. The bay is a semi-enclosed basin with relatively high organic content in the sediment and a predominantly muddy bottom. Samples were collected using hand-held cores and preserved in $8 \%$ buffered formalin. Sediment samples were processed by sieving over two sieves with 500 and $45 \mu \mathrm{m}$ mesh size and specimens were extracted by the flotation technique using a high-density sugar solution $\left(1.16 \mathrm{~g} \mathrm{~cm}^{-3}\right)$. Sorted animals were transferred to anhydrous glycerin and mounted on glass slides.

The description and drawings were made using a Leica DMR phase contrast microscope (maximum magnification $1500 \times$ ) with drawing tube. Measurements of straight and curved features were taken with a ruler and a curvimeter, respectively, with $1 \mu \mathrm{m}$ of error at highest magnification and $c a 60 \mu \mathrm{m}$ for longer measurements such as body length. The taxonomic classification of Lorenzen (1994) was followed at taxonomic levels above genus.

\section{Descriptions}

\section{Family Xyalidae Chitwood, 1951}

\section{DiAgNOSIS (EMENDED)}

The present diagnosis is based mainly on Lorenzen (1994), Nicholas and Trueman (2002) and on features of the new genus.

\section{Order Monhysterida Filipjev, 1929}

Body cuticle fine to coarsely annulated; annules smooth or ornamented with longitudinal striae, single or Vshaped ridges. Second and third circles of anterior sensilla inserted at same level or very close, exceptionally in two separate circles (Guitartia tridentata n. gen., n. sp.). Female with single anterior ovary located to left of intestine (exceptionally right of intestine in Hofmaenneria niddensis Gerlach \& Meyl, 1957 and Steineria pilosa (Cobb, 1914) Micoletzky, 1922b), with or without a postvulvar sac. Male diorchic or monorchic.

\section{Guitartia* n. gen.}

\section{DiagnOSIS}

Xyalidae Chitwood, 1951

Body cuticle with fine transverse striation. Stoma narrow, cylindrical, with three long teeth-like structures

\footnotetext{
* Named in honour of the late Prof. Dr Dario Guitart, Emeritus Professor at the University of Havana, and professor of several generations of marine biologists in Cuba.
} 
appearing bifid at tip. Pattern of anterior sensilla $6+6+4$, first circle probably papilliform but not visible by light microscopy, second and third circles of setiform anterior sensilla separate and of similar length. Amphidial fovea round, relatively large (more than $50 \%$ of corresponding body diameter (cbd)). Female reproductive system with one anterior outstretched ovary, located to left of intestine, post-vulvar sac present. Male reproductive system with anterior outstretched testis, located to left of intestine. Gubernaculum with short dorso-caudal apophyses. Tail with three caudal glands, terminal setae at tail tip absent.

\section{TYPE AND ONLY SPECIES}

Guitartia tridentata n. gen., n. sp.

\section{RELATIONSHIPS}

Guitartia n. gen. belongs to the Monhysterida in having an outstretched ovary, a holapomorphy for the order. The new genus is classified within the superfamily Monhysteroidea due to holapomorphy of a single anterior ovary (Lorenzen, 1994). Other features, such as the round amphidial fovea and pharynx lacking a proper posterior bulb, also suggest membership of this superfamily. Within the Monhysteroidea, Guitartia n. gen. is classified in the Xyalidae due to the anterior gonad (ovary or testis) being located to the left of the intestine. Other features supporting classification within the Xyalidae are the transverse striation of the body cuticle, six outer labial sensilla being about equal or slightly shorter in length than the four cephalic setae of the third circle of anterior sensilla, stegostom well developed and surrounded by pharyngeal tissue but gymnostom reduced or absent, and ventral gland apparently absent.

The Xyalidae is taxonomically a difficult group because of high morphological diversity, relationships within the family not being completely resolved and several genera appearing paraphyletic (Nicholas \& Trueman, 2002). Based on the phylogenetic tree obtained, the authors recognised 15 groups, only a few representing clades. An attempt to place the new genus within the cladistic analysis by Nicholas and Trueman (2002) did not show any clade/group where the new genus could be included. In addition, a further subdivision of the family into three subfamilies (Rhynchonematinae De Coninck, 1965, Cobbiinae De Coninck, 1965, and Corononeminae Nicholas \& Stewart, 1995) has no clear phylogenetic basis (Nicholas \& Trueman, 2002) so we did not include Guitartia n. gen. in any subfamily.
Two relatively conspicuous morphological features allow an initial discrimination of the new genus within the Xyalidae, viz., the sclerotisation of the stoma and the structure and ornamentation of the body cuticle. The presence of sclerotised tooth-like structures is relatively uncommon in the Xyalidae (see genera below) and allows the differentiation of the new genus from the speciesrich genera Daptonema Cobb, 1920 and Theristus Bastian, 1865. The relatively simple pattern of transverse striation of the body cuticle of Guitartia n. gen. (i.e., no longitudinal striae, punctations or ridges) allows further discrimination from other genera like Gonionchus Cobb, 1920 (only G. heipi Vincx, 1986 has simple transverse striation), Omicronema Cobb, 1920, Rhynchonema Cobb, 1920 and Xyala Cobb, 1920. Table 1 shows the morphologically most similar genera to the new genus within Xyalidae and the most useful features for species differentiation. However, even the genera included in Table 1 are highly divergent in morphology.

\section{Guitartia tridentata* ${ }^{*}$. gen., n. sp. (Fig. 1)}

\section{MEASUREMENTS}

See Table 2.

\section{DESCRIPTION}

\section{Adults}

Body slender, tail with long filiform portion. Body cuticle with fine transverse striation (striae $c a 1 \mu \mathrm{m}$ apart) except for smooth head region. Anterior sensilla pattern $6+6+4$, inner labial sensilla papilliform, not visible with light microscope, outer labial setae and cephalic setae at different level (circles) and of $c a$ same length. Four submedian cervical setae arranged in one circle posterior to amphidial fovea, 10-12 $\mu \mathrm{m}$ long, one pair of lateral setae $(10-12 \mu \mathrm{m})$ immediately posterior to fovea. Somatic setae rare, one precloacal seta present in male. Amphidial fovea large, round, located at level of posterior stoma. Cheilostom present, no apparent gymnostom, stegostom long, tubular, only posteriorly narrowing, surrounded by pharyngeal tissue, walls of lumen well sclerotised, anteriorly provided with three tooth-like structures (13 $\mu \mathrm{m}$ long) with anterior bifid tip

\footnotetext{
* Specific epithet named in respect of the three teeth present in the buccal cavity.
} 
Table 1. Main morphological features differentiating Guitartia $n$. gen. from most similar genera within family Xyalidae (cbd = corresponding body diam.).

\begin{tabular}{|c|c|c|c|c|c|}
\hline Genus & Stoma armature & $\begin{array}{l}\text { Amphidial } \\
\text { fovea }\end{array}$ & Posterior genital branch & $\begin{array}{c}\text { Gubernacular } \\
\text { apophyses }\end{array}$ & $\begin{array}{c}\text { Terminal } \\
\text { setae }\end{array}$ \\
\hline Amphimonhystrella Timm, 1961 & Weakly sclerotised & $>0.5 \mathrm{cbd}$ & Poorly developed & Absent & Present \\
\hline Cobbia de Man, 1907 & Three teeth & $<0.5 \mathrm{cbd}$ & Absent & Absent & Absent \\
\hline Elzalia Gerlach, 1957 & Heavily sclerotised & $>0.5 \mathrm{cbd}$ & Absent or poorly developed & Absent & Present \\
\hline Guitartia n. gen. & Processes teeth-like & $>0.5 \mathrm{cbd}$ & Poorly developed & Present & Absent \\
\hline Scaptrella Cobb, 1917 & Six odontia & $<0.5 \mathrm{cbd}$ & $?$ & Absent & Present \\
\hline Valvaelaimus Lorenzen, 1977 & Processes teeth-like & $<0.5 \mathrm{cbd}$ & Poorly developed & Absent & Absent \\
\hline
\end{tabular}

Table 2. Morphometrics of Guitartia tridentata n. gen., $n$. sp. All measurements are in $\mu \mathrm{m}$.

\begin{tabular}{lcccc}
\hline Character & Male & & \multicolumn{2}{c}{ Female } \\
\cline { 2 - 3 } \cline { 5 - 5 } \cline { 5 - 5 } & Holotype & & Paratype 1 & Paratype 2 \\
\hline L & 1750 & & 1750 & 1813 \\
$\mathrm{a}$ & 70.0 & & 62.5 & 32.4 \\
$\mathrm{~b}$ & 10.0 & & 9.3 & 9.6 \\
$\mathrm{c}$ & 5.0 & & 4.7 & 5.0 \\
$\mathrm{c}^{\prime}$ & 19.4 & & 18.8 & 14 \\
V (\%) & - & & 59 & $*$ \\
Head diam. & 16 & & 15 & 22 \\
Length of outer labial setae & 16 & & 16 & 18 \\
Length of cephalic setae & 14 & & 15 & 16 \\
Stegostom diam. & 4 & & 4 & 7 \\
Amphidial fovea from & 6 & & 8 & 11 \\
$\quad$ anterior end & & & & \\
Amphidial fovea diam. & 16 & & 12 & 15 \\
Position of nerve ring $(\%)$ & 54 & & 50 & $n .0$. \\
Max. body diam. & 25 & & 28 & 56 \\
Anterior genital branch & 833 & & 132 & $*$ \\
Posterior genital branch & - & & 69 & $*$ \\
Spicule (arc) & 25 & & - & - \\
Spicule (chord) & 20 & & - & - \\
Gubernaculum & 4 & & - & - \\
Gubernacular apophyses & 5 & & - & - \\
Anal body diam. & 18 & & 20 & 26 \\
Tail & 350 & & 375 & 363 \\
Conical portion of tail (\%) & 36 & & 43 & 41 \\
\hline & & & &
\end{tabular}

* specimen damaged.

n.o., not observable.

(visible as six tips at anterior border stegostom). Pharynx largely cylindrical, gradually enlarging posteriorly but without a proper pharyngeal bulb, pharyngeal glands apparently with outlet anteriorly in stoma. Cardia weakly developed, variable in shape. Ventral gland, duct and opening apparently absent. Tail conical-cylindrical with three caudal glands and small spinneret at tail tip.

\section{Male}

Monorchic, testis to left of intestine, vesicula seminalis with large cells, vas deferens with differentiated granulation. Spicules ventrally curved, no offset capitulum, lamina mostly of equal width, only tapering towards distal tip, velum absent. Gubernaculum with short dorsal apophyses. No precloacal supplements, only a single precloacal seta present.

\section{Female}

Monodelphic, anterior single genital branch arranged to left of intestine, ovary outstretched, posterior branch not developed except for a post-vulvar sac (spermatheca). Vagina anteriorly directed, with weakly sclerotised lumen wall.

\section{TYPE HABITAT AND LOCALITY}

Subtidal muddy bottom at Cienfuegos Bay, Caribbean Sea $\left(22^{\circ} 9^{\prime} \mathrm{N}, 80^{\circ} 27^{\prime} \mathrm{W}\right)$. Collected in the wet and dry seasons in 2006 by M. Armenteros.

\section{TYPE MATERIAL}

Holotype male (specimen 985.I.5) deposited in Centro Nacional de Colecciones Marinas, Acuario Nacional de Cuba (CNCM-ANC). One paratype female deposited in the CNCM-ANC (specimen 1029.D.5) and in the nematode collection of the Royal Belgian Institute of Natural Sciences (specimen RIT764).

\section{DiAgnosis}

Guitartia tridentata n. gen., n. sp. is characterised by the relatively long outer labial and cephalic setae which are of similar length (15-18 $\mu \mathrm{m})$, large, round, amphidial fovea (more than $50 \%$ of cbd), spicules 1.4 anal body 
A

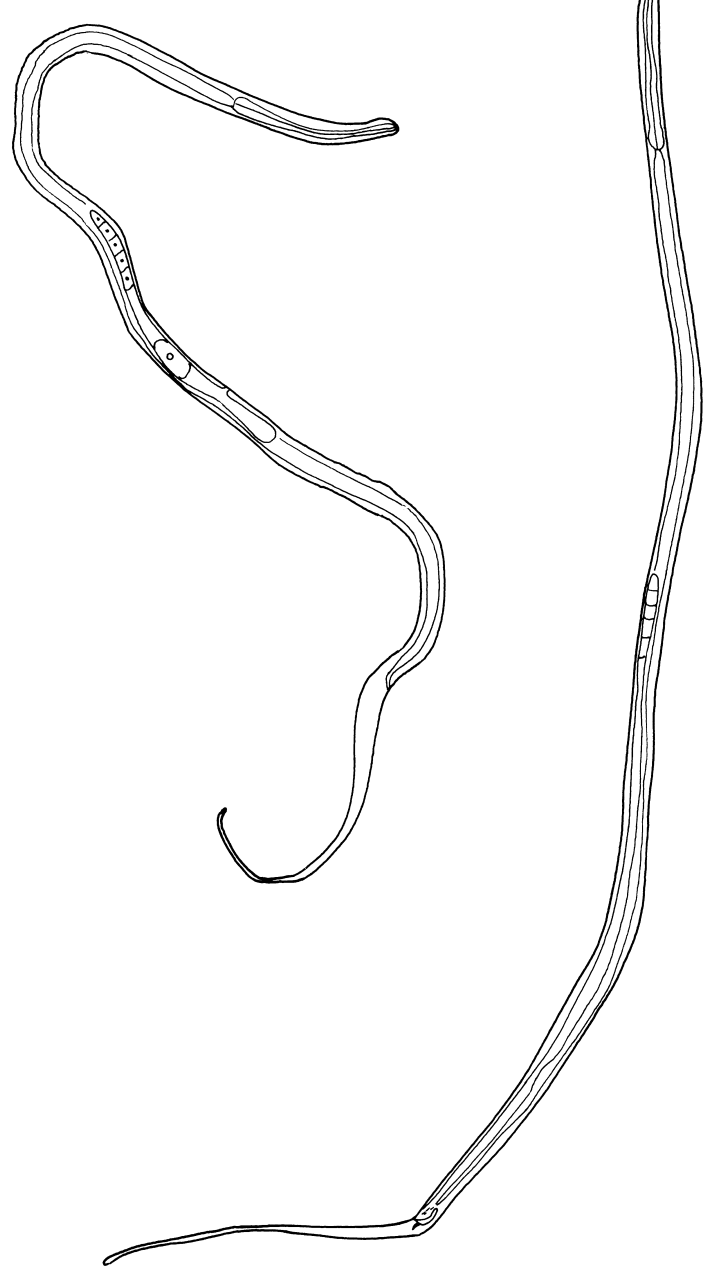

C

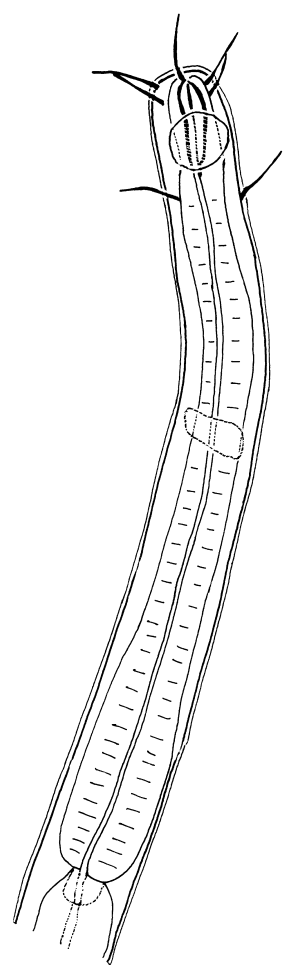

D

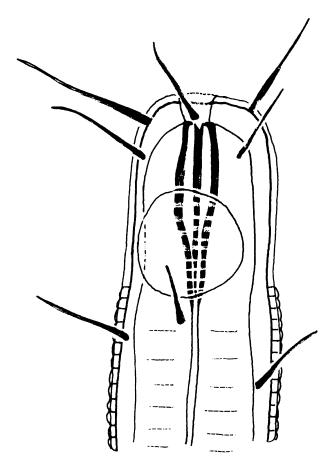

$\mathbf{E}$

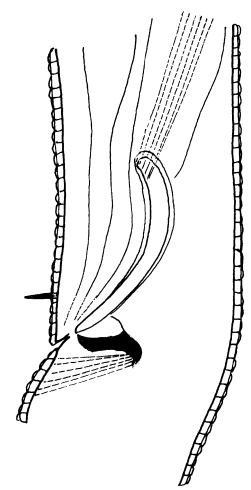

\section{A, B: $200 \mu \mathrm{m}$ \\ C: $40 \mu \mathrm{m}$}

D, E, F: $20 \mu \mathrm{m}$

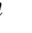


diam. long, ventrally curved and without offset capitulum, precloacal supplements absent and tail with long, filiform, posterior portion.

\section{ECOLOGICAL REMARKS}

Specimens of Guitartia tridentata n. gen., n. sp. were collected from muddy and organically enriched bottom sediments. They probably show some tolerance to hypoxic conditions and chemical pollution as the concentration of some metals in these sediments (chromium, copper, nickel, vanadium) was high.

\section{Macrodontium* n. gen.}

\section{DiAgNOSIS}

\section{Microlaimidae Micoletzky, 1922 a}

Body cuticle transversely striated. Four cephalic sensilla, larger than six outer labial sensilla. Amphidial fovea cryptospiral without protruding corpus gelatum, larger in male (sexual dimorphism). Stoma rather large, sclerotised, armed with a large dorsal tooth, two minute consecutive subventral teeth. Pharynx without differentiated anterior part but with terminal bulb. Male monorchic, gubernaculum with one well developed dorso-caudal apophysis. Female didelphic-amphidelphic with outstretched ovaries. Tail conico-cylindrical.

\section{TYPE AND ONLY SPECIES}

Macrodontium gaspari n. gen., n. sp.

\section{RELATIONSHIPS}

The main morphological features differentiating the new genus from other genera within Microlaimidae are summarised in Table 3. The most conspicuous feature of Macrodontium gen. $\mathrm{n}$. is the presence of a well sclerotised stoma with one large dorsal tooth and two consecutive subventral teeth, a combination suggesting Acanthomicrolaimus and Bolbolaimus as similar genera. Macrodontium gen. n. differs from the former genus in having the body cuticle simply transversely striated vs covered with spine-like ornamentations and from the latter genus by cephalic sensilla longer than outer labial sensilla $v s$ shorter.

Within the family Microlaimidae, most genera possess males with two testes and only two genera, Bathynox and

\footnotetext{
* The generic name refers to the large tooth.
}

Crassolaimus, have males with a single testis as observed in the new genus (note that in Acanthomicrolaimus the posterior testis is reduced). Aponema is the only genus in the family that shows a mixture of the monorchic and diorchic condition with four monorchic species and two diorchic species, namely $A$. decraemerae Muthumbi \& Vincx, 1999 and A. mnazi Muthumbi \& Vincx, 1999. The new genus differs from Bathynox by the form of the stoma, non-pedunculate somatic setae and anterior position of the amphidial fovea without protruding corpus gelatum ( $v s$ weakly sclerotised stoma, somatic setae on peduncles, amphidial fovea located near mid-pharynx, amphid opening small and protruding corpus gelatum). Macrodontium gen. n. differs from Crassolaimus by stoma armature with sclerotised walls and large dorsal tooth, presence of a gubernacular apophysis and absence of precloacal supplements $v s$ small dorsal indentation in stoma, absence of gubernacular apophysis and presence of precloacal supplements.

The new genus shows some similarities with Aponema in body cuticle arrangement, sexual dimorphism in size of amphidial fovea (larger in males), presence of a gubernacular apophysis and conical-cylindrical tail shape. It differs from Aponema mainly by the stoma sclerotisation, the monorchic condition (partim in Aponema) and the number of gubernacular apophyses.

The genus Microlaimus is the most species-rich in the family, showing interspecific morphological variability in shape and size of amphidial fovea and tail shape. However, the heavy sclerotisation of the stoma and presence of an apophysis are important diagnostic features for discrimination between Macrodontium n. gen. and Microlaimus.

\section{Macrodontium gaspari*** nen., n. sp. (Fig. 2)}

\section{MEASUREMENTS}

See Table 4.

\section{DESCRIPTION}

\section{Adults}

Body slender, anterior half slightly broader than posterior half. Body cuticle transversely striated, striae $c a 1 \mu \mathrm{m}$

\footnotetext{
** Named in honour of Prof. Dr Gaspar González-Sansón, Professor of Marine Ecology at the University of Havana, Cuba, and leader of marine research in Cuba.
} 
Table 3. Main morphological features differentiating the genus Macrodontium $n$. gen. from the other genera within the Microlaimidae.

\begin{tabular}{|c|c|c|c|c|c|c|c|c|}
\hline Genus & $\begin{array}{l}\text { Striation } \\
\text { of cuticle }\end{array}$ & $\begin{array}{l}\text { Somatic } \\
\text { setae }\end{array}$ & $\begin{array}{l}\text { Cephalic } \\
\text { sensilla* }\end{array}$ & $\begin{array}{l}\text { Amphidial } \\
\text { fovea }\end{array}$ & Stoma armature & Testis & $\begin{array}{l}\text { Gubernacular } \\
\text { apophysis }\end{array}$ & Tail \\
\hline $\begin{array}{l}\text { Acanthomicrolaimus } \\
\text { Stewart \& } \\
\text { Nicholas, } 1987\end{array}$ & Coarse & $\begin{array}{l}\text { Like } \\
\text { spines }\end{array}$ & Longer & $\begin{array}{l}\text { Cryptospiral, } \\
<0.5 \text { cbd }\end{array}$ & $\begin{array}{l}\text { Heavily sclerotised, one } \\
\text { larger dorsal tooth, two } \\
\text { ventral }\end{array}$ & $\begin{array}{l}\text { Poste- } \\
\text { rior } \\
\text { reduced }\end{array}$ & One, dorsal & Conical \\
\hline $\begin{array}{l}\text { Aponema } \\
\quad \text { Jensen, } 1978\end{array}$ & Fine & Scarce & Longer & $\begin{array}{l}\text { Cryptospiral, } \\
\text { sexual dimor- } \\
\text { phism }\end{array}$ & $\begin{array}{l}\text { Weakly sclerotised, } \\
\text { unarmed or with one } \\
\text { minute dorsal and two } \\
\text { ventrosublateral teeth }\end{array}$ & $\begin{array}{l}\text { Single } \\
\text { anterior } \\
\text { or two }\end{array}$ & $\begin{array}{l}\text { Two, } \\
\text { dorsocaudal }\end{array}$ & $\begin{array}{l}\text { Conico- } \\
\text { cylin- } \\
\text { drical or } \\
\text { conical }\end{array}$ \\
\hline $\begin{array}{l}\text { Bathynox Bussau \& } \\
\text { Vopel, } 1999\end{array}$ & Coarse & $\begin{array}{l}\text { On pe- } \\
\text { duncles }\end{array}$ & Longer & $\begin{array}{l}<0.5 \text { cbd, } \\
\text { corpus gela- } \\
\text { tum protruded }\end{array}$ & $\begin{array}{l}\text { Weakly sclerotised, one } \\
\text { small dorsal and one or } \\
\text { two small subventral }\end{array}$ & $\begin{array}{l}\text { Single } \\
\text { anterior }\end{array}$ & Reduced & Conical \\
\hline $\begin{array}{l}\text { Bolbolaimus } \\
\quad \text { Cobb, } 1920\end{array}$ & Fine & Scarce & Longer & $\begin{array}{l}\text { Cryptospiral, } \\
<0.5 \text { cbd }\end{array}$ & $\begin{array}{l}\text { Heavily sclerotised, one } \\
\text { larger dorsal tooth, two } \\
\text { pairs of smaller ventrosub- } \\
\text { lateral teeth or denticles }\end{array}$ & Two & $?$ & Conical \\
\hline $\begin{array}{l}\text { Caligocanna Bussau } \\
\text { \& Vopel, } 1999\end{array}$ & $\begin{array}{l}\text { Coarse } \\
\text { with lon- } \\
\text { gitudinal } \\
\text { bars }\end{array}$ & Scarce & Shorter & Cryptospiral & $\begin{array}{l}\text { Two dorsal anterior, two } \\
\text { posterior teeth }\end{array}$ & Two & Absent & Conical \\
\hline $\begin{array}{l}\text { Calomicrolaimus } \\
\text { Lorenzen, } 1976\end{array}$ & Coarse & Scarce & Longer & $\begin{array}{l}\text { Cryptospiral, } \\
\text { sexual dimor- } \\
\text { phism, corpus } \\
\text { gelatum } \\
\text { protruded }\end{array}$ & $\begin{array}{l}\text { Weakly sclerotised, one } \\
\text { small dorsal and two } \\
\text { minute subventral teeth }\end{array}$ & $\begin{array}{l}\text { Two, } \\
\text { poste- } \\
\text { rior } \\
\text { can be } \\
\text { reduced }\end{array}$ & Absent & Conical \\
\hline $\begin{array}{l}\text { Cinctonema } \\
\quad \text { Cobb, } 1920\end{array}$ & Coarse & Scarce & Longer & $\begin{array}{l}\text { Round or } \\
\text { cryptospiral, } \\
<0.5 \text { cbd }\end{array}$ & $\begin{array}{l}\text { Weakly sclerotised, one } \\
\text { small dorsal and two small } \\
\text { ventrosublateral teeth }\end{array}$ & $?$ & $?$ & Conical \\
\hline $\begin{array}{r}\text { Crassolaimus } \\
\text { Kreis, } 1929\end{array}$ & Fine & Scarce & Longer & $\begin{array}{l}\text { Cryptospiral, } \\
<0.5 \text { cbd }\end{array}$ & $\begin{array}{l}\text { Weakly sclerotised; a sin- } \\
\text { gle ventral tooth opposite } \\
\text { indentation dorsal wall }\end{array}$ & $\begin{array}{l}\text { Single } \\
\text { anterior }\end{array}$ & Absent & Conical \\
\hline $\begin{array}{l}\text { Ixonema } \\
\quad \text { Lorenzen, } 1971\end{array}$ & Absent & $\begin{array}{l}\text { Rows } \\
\text { of long } \\
\text { setae }\end{array}$ & Longer & $\begin{array}{l}<0.5 \text { cbd, } \\
\text { corpus gela- } \\
\text { tum protruded }\end{array}$ & $\begin{array}{l}\text { Weakly sclerotised; one } \\
\text { dorsal and two smaller con- } \\
\text { secutive subventral teeth }\end{array}$ & Two & Absent & Conical \\
\hline $\begin{array}{l}\text { Macrodontium } \\
\text { n. gen. }\end{array}$ & Fine & Scarce & longer & $\begin{array}{l}\text { Cryptospiral, } \\
\text { sexual dimor- } \\
\text { phism }\end{array}$ & $\begin{array}{l}\text { Heavily sclerotised, one } \\
\text { larger dorsal tooth, two } \\
\text { minute consecutive sub- } \\
\text { ventral teeth }\end{array}$ & $\begin{array}{l}\text { Single } \\
\text { anterior }\end{array}$ & $\begin{array}{l}\text { One, } \\
\text { dorsocaudal }\end{array}$ & $\begin{array}{l}\text { Conico- } \\
\text { cylin- } \\
\text { drical }\end{array}$ \\
\hline $\begin{array}{l}\text { Microlaimus } \\
\text { de Man, } 1880\end{array}$ & Coarse & Scarce & Longer & $\begin{array}{l}\text { Round or } \\
\text { cryptospiral, } \\
>\text { or }<0.5 \text { cbd }\end{array}$ & $\begin{array}{l}\text { Weakly sclerotised; one } \\
\text { small dorsal and two } \\
\text { minute subventral teeth }\end{array}$ & Two & Absent & $\begin{array}{l}\text { Conical } \\
\text { or } \\
\text { conico- } \\
\text { cylin- } \\
\text { drical }\end{array}$ \\
\hline $\begin{array}{l}\text { Spirobolbolaimus } \\
\text { Soetaert \& Vincx, } \\
1988\end{array}$ & Coarse & Scarce & Shorter & Multispiral & $\begin{array}{l}\text { Weakly sclerotised; one } \\
\text { small dorsal tooth, a pair } \\
\text { of posterior ventrosublat- } \\
\text { eral teeth and a pair of an- } \\
\text { terior tooth-like projections }\end{array}$ & Two & Absent & Conical \\
\hline
\end{tabular}

\footnotetext{
* Length relative to outer labial sensilla.
} cbd, corresponding body diam. 

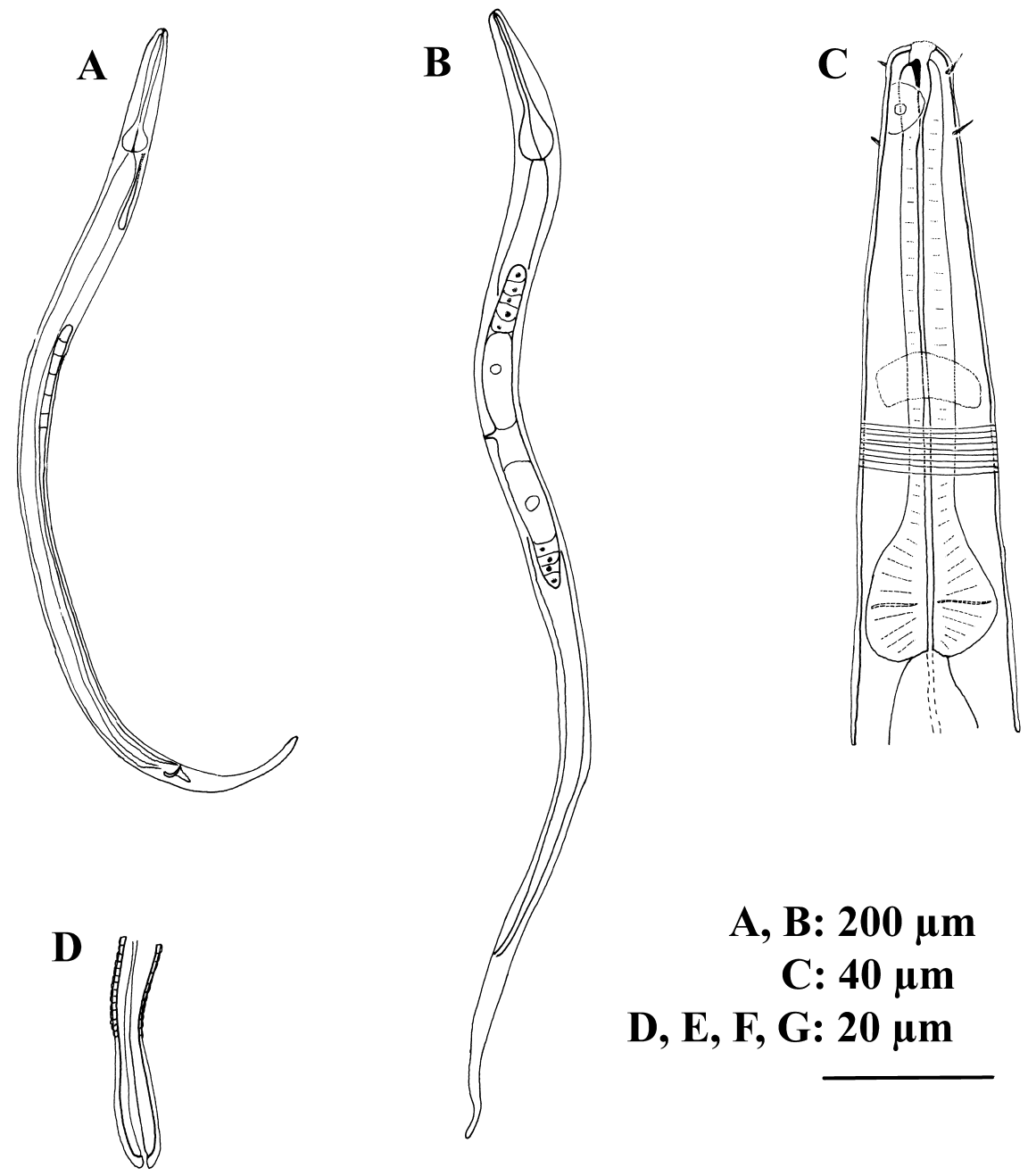

G

E

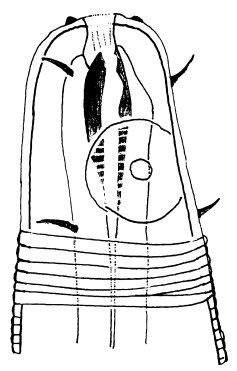

F

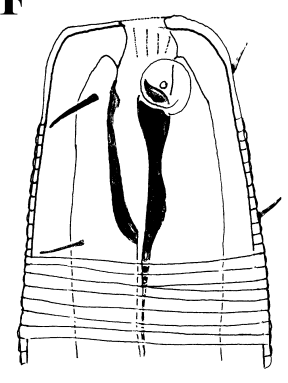

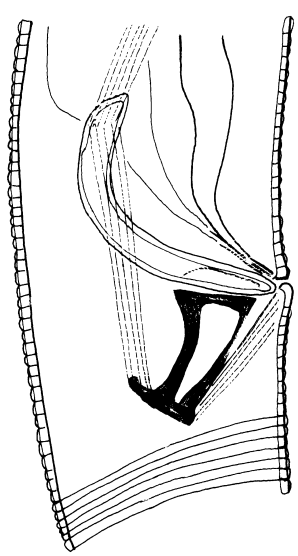

Fig. 2. Macrodontium gaspari n. gen., n. sp. A: Habitus of holotype male; B: Habitus of a paratype female; C: Neck region of holotype; D: Tail tip of holotype; E: Head region of holotype; F: Head region of a paratype female; G: Spicular apparatus of holotype. 
Table 4. Morphometrics of Macrodontium gaspari $n$. gen., $n$. sp. All measurements are in $\mu$ m and in the format: mean (range).

\begin{tabular}{|c|c|c|c|c|}
\hline \multirow[t]{2}{*}{ Character } & \multicolumn{2}{|c|}{ Male } & \multirow{2}{*}{$\begin{array}{c}\text { Female } \\
\text { Paratypes }\end{array}$} & \multirow{2}{*}{$\begin{array}{c}\text { Juvenile } \\
\text { Paratypes }\end{array}$} \\
\hline & Holotype & Paratypes & & \\
\hline $\mathrm{n}$ & - & 9 & 10 & 10 \\
\hline $\mathrm{L}$ & 1063 & $1137(1065-1300)$ & $1242(1125-1375)$ & $963(730-1125)$ \\
\hline $\mathrm{a}$ & 30.4 & $26.7(21.0-31.4)$ & $25.6(19.4-31.3)$ & $24.2(19.3-34.4)$ \\
\hline $\mathrm{b}$ & 7.1 & $7.7(7.0-8.7)$ & $7.6(6.4-8.3)$ & $7.0(6.3-7.8)$ \\
\hline $\mathrm{c}$ & 6.5 & $6.9(6.1-7.8)$ & $6.2(5.3-6.9)$ & $5.9(4.9-6.8)$ \\
\hline$c^{\prime}$ & 6.3 & $5.5(4.4-6.3)$ & $8.3(5.5-9.7)$ & $7.4(6.3-9.6)$ \\
\hline V & - & - & $40(31-44)$ & - \\
\hline Head diam. & 13 & $16(13-19)$ & $19(16-24)$ & $15(11-20)$ \\
\hline Length of cephalic setae & 2 & $3(2-3)$ & $4(2-4)$ & $3(2-4)$ \\
\hline Stegostom diam. & 3 & $4(3-5)$ & $5(2-6)$ & $4(2-5)$ \\
\hline Amphidial fovea from anterior end & 7 & $8(6-10)$ & $5(3-8)$ & $5(2-7)$ \\
\hline Amphidial fovea diam. & 10 & $11(10-12)$ & $4(4-5)$ & $4(3-4)$ \\
\hline Position of nerve ring (\%) & 46 & $47(46-51)$ & $43(38-47)$ & $45(36-50)$ \\
\hline Max. body diam. & 35 & $44(34-56)$ & $51(40-62)$ & $41(29-57)$ \\
\hline Anterior genital branch & 600 & $581(467-667)$ & $171(100-213)$ & - \\
\hline Posterior genital branch & - & - & $159(88-200)$ & - \\
\hline Spicule (arc) & 38 & $35(31-44)$ & - & - \\
\hline Spicule (chord) & 23 & $25(22-29)$ & - & - \\
\hline Gubernaculum & 7 & $7(6-10)$ & - & - \\
\hline Gubernacular apophyses & 18 & $17(13-19)$ & - & - \\
\hline Anal body diam. & 26 & $30(26-35)$ & $25(22-32)$ & $22(17-28)$ \\
\hline Tail & 163 & $165(148-188)$ & $204(175-213)$ & $163(125-200)$ \\
\hline Conical part of tail (\%) & 85 & $89(85-93)$ & $87(82-94)$ & $86(77-93)$ \\
\hline
\end{tabular}

apart, head region and tail terminus smooth, cuticle showing lateral differentiation visible as a groove from cardia level to cloacal aperture (not seen in all specimens, probably dependent on preservation). Head region about as broad as long, slightly marked by depression at level of amphidial fovea. Anterior sensilla pattern $6+6+4$, six inner labial sensilla not visible, six outer labial sensilla minute, rarely visible, four submedian cephalic setae at level of (female and juveniles), or anterior to (male), anterior border of amphidial fovea. Four submedian cervical setae, in male located immediately posterior to fovea. Somatic setae rare; short somatic setae scattered in tail region. Stegostom lumen weakly sclerotised, provided with large dorsal tooth and two minute, consecutive, subventral teeth, posterior one slightly larger than anterior. Amphidial fovea crypto-spiral, external circle interrupted in posterior wall, fovea $c a$ twice as large in male as female. Pharynx muscular, with developed posterior bulb. Ventral gland immediately posterior to pharyngeal bulb, not easily seen in majority of specimens, secretory-excretory pore and ampulla not observed. Cardia rather small, surrounded by intestine. Three caudal glands within tail, dif- ficult to observe in most specimens, with common outlet. Tail mostly conical with slightly swollen tip.

Male

Single anterior testis located to right of intestine, vas deferens long, narrow. Spicules ventrally curved, noncephalated. Gubernaculum with small corpus but one well developed dorso-caudal apophysis with sclerotised borders and hammer-like terminus (proximal end for attachment of protractor muscles).

\section{Female}

Genital system didelphic, amphidelphic. Both ovaries outstretched, often with one egg in each uterus. Position of genital branches regarding intestine variable, either to left or right of intestine. Vulva pre-median, relatively anterior in position, lumen wall relatively sclerotised.

\section{TYPE HABITAT AND LOCALITY}

Subtidal muddy bottom at Cienfuegos Bay, Caribbean Sea $\left(22^{\circ} 9^{\prime} \mathrm{N}, 80^{\circ} 27^{\prime} \mathrm{W}\right)$. Collected in wet and dry seasons in 2006 by M. Armenteros. 


\section{TYPE MATERIAL}

Holotype male (specimen 550.D.1) deposited in Centro Nacional de Colecciones Marinas, Acuario Nacional de Cuba (CNCM-ANC). Three paratypes (two males and one female; specimens 550.D.3, 550.I.5, and 576.I.4, respectively) deposited in CNCM-ANC; three paratypes (two males and one female, specimens RIT764) deposited in Royal Belgian Institute of Natural Science, Belgium. Other paratype specimens deposited in the personal collection of the first author at the Centro de Investigaciones Marinas, Universidad de La Habana, Cuba.

\section{DiAgNOSIS}

The new species is characterised by sexual dimorphism in size and shape of the amphidial fovea, size and shape of spicules (31-44 $\mu \mathrm{m}$, non-cephalated) and gubernaculum (6-10 $\mu \mathrm{m}$ with one apophysis), absence of precloacal supplements.

\section{ECOLOGICAL REMARKS}

Individuals of Macrodontium gaspari n. gen., n. sp. were common in muddy, organically enriched, bottom sediments subjected to pollution by heavy metals and hydrocarbons in Cienfuegos Bay. Specimens were always collected in the upper $2 \mathrm{~cm}$ of the sediment and were absent below this depth. The species appears to be tolerant to chemical pollution since it was relatively abundant in sediment with high concentrations of heavy metals.

\section{Acknowledgements}

We thank the International Foundation of Science (research grant A-4004/1 to M.A.) for financial support and Ghent University (doctoral scholarship BOF 01W01607 to M.A.). The Belgian Focal Point to the Global Taxonomy Initiative (project 2406JVG2) assisted with the taxonomic expertise and equipment necessary for this research. We acknowledge two anonymous referees for improving the manuscript with their comments and corrections.

\section{References}

ALlGÉN, C. (1958). Über einige freilebende marine Nematoden von der Ostküste Südamerikas (Uruguay, Nordküste Argentinas). Zoologischer Anzeiger 160, 206-217.
Armenteros, M., Vincx, M. \& Decraemer, W. (2009). Cienfuegia gen. nov. (Xyalidae) and Pseudoterschellingia gen. nov. (Linhomoeidae), two new genera of free-living marine nematodes from the Caribbean Sea. Journal of Natural History 43, 1067-1081.

BASTIAN, H.C. (1865). Monograph on the Anguillulidae, or free nematoids, marine, land, and freshwater; with descriptions of 100 new species. Transactions of the Linnean Society of London 25, 73-184.

Blome, D. (2002). Five new genera of free-living marine nematodes from sandy beaches of eastern Australia. Memoirs of the Queensland Museum 48, 29-43.

Bussau, C. (1993). Taxonomische und ökologische Untersuchungen an Nematoden des Peru-Beckens. Ph.D. Thesis, Kiel University, Kiel, 621 pp.

Bussau, C. \& Vopel, K. (1999). New nematode species and genera (Chromadorida, Microlaimidae) from the deep sea of the eastern tropical South Pacific (Peru Basin). Annalen des Naturhistorichen Museums in Wien 101B, 405-421.

Chitwood, B.G. (1951). North American marine nematodes. Texas Journal of Science 3, 617-672.

Совв, N.A. (1914). Antarctic marine free-living nematodes of the Shackleton Expedition. Contributions to a science of nematology. I. Baltimore, MD, USA, Williams \& Wilkins, $33 \mathrm{pp}$.

Совв, N.A. (1920). One hundred new nemas. Contributions to a science of nematology 9, 217-234.

De ConincK, L.A. (1965). Classe des Nématodes - Systématique des nématodes et sous-classe des Adenophorea. In: Grassé, P.-P. (Ed.). Traité de zoologie. Paris, France, Masson et Cie, pp. 586-681.

FilipJeV, I. (1929). Classification of free-living Nematoda and relations to parasitic forms. Journal of Parasitology 15, 281-282.

Gerlach, S.A. \& MeYL, A.H. (1957). Freilebende Nematoden aus dem Ohrid-See. Beaufortia 5, 157-170.

HuANG, Y. \& ZHANG, Z.N. (2006). A new genus and three new species of free-living marine nematodes from the Yellow Sea, China. Journal of Natural History 40, 5-16.

Jensen, P. (1978). Revision of Microlaimidae, erection of Molgolaimidae fam. n., and remarks on the systematic position of Paramicrolaimus (Nematoda, Desmodorida). Zoologica Scripta 7, 159-173.

KREIS, H.A. (1929). Freilebende marine Nematoden von der Nordwestkueste Frankreichs (Trébeurden: Côtes du Nord). Capita Zoologica 2, 112.

LORENZEN, S. (1971). Ixonema sordidum gen. n., sp. n. (Microlaimidae, Nematoda) aus sublitoralem Grobsand bei Helgoland. Marine Biology 8, 267-269.

LORENZEN, S. (1976). Desmodoridae (Nematoden) mit extrem langen Spicula aus Südamerika. Mitteilungen der Institute Colombo - Aleman Investigaciones Científicas 8, 63-77.

LORENZEN, S. (1994). The phylogenetic systematics of freeliving nematodes. London, UK, The Ray Society, 383 pp. 
DE MAN, J.G. (1880). Die Einheimischen, frei in der reinen Erde und im süssen Waser lebende Nematoden monographisch bearbeitet. Vorläufiger Bericht und descriptive-systematischer Theil. Tijdschrift der Nederlandsche Dierkundige Vereeniging 5, 1-104.

Meldal, B.H.M., Debenham, N.J., De Ley, P., TANDinGAN DE Ley, I., VAnfleteren, J.R., Vierstraete, A.R., Bert, W., Borgonie, G., Moens, T., Tyler, P.A., Austen, M.C., Blaxter, M.L., Rogers, A.D. \& LAMBSHEAD, P.J.D. (2007). An improved molecular phylogeny of the Nematoda with special emphasis on marine taxa. Molecular Phylogenetics and Evolution 42, 622-636.

MicoletZKY, H. (1922a). Zur Nematodenfauna des Bodensees. Internationale Revue der Gesamten Hydrobiologie und Hydrographie 10, 491-512.

MicoletzKy, H. (1922b). Die freilebenden Erdnematoden. Archiv für Naturgeschichte 87A, 1-650.

Muthumbi, A.W. \& Vincx, M. (1999). Microlaimidae (Microlaimoidea: Nematoda) from the Indian Ocean: description of nine new and known species. Hydrobiologia 397, 39-58.

Nicholas, W.L. \& Stewart, A.C. (1995). New genera, species and a new subfamily of Xyalidae (Nematoda, Monhysterida) from ocean beaches in Australia and Thailand. Transactions of the Royal Society of South Australia 119, 47-66.

Nicholas, W.L. \& Trueman, J.W.H. (2002). The taxonomy of the family Xyalidae Chitwood, 1951 (Monhysterida: Nematoda): a cladistic analysis. Nematology 4, 453-470.
Shoshin, A. (2001). Sacrimarinema gen. n. from Lake Baikal with descriptions of three new species (Nematoda, Monhysterida: Xyalidae). Zoosystematica Rossica 9, 253-257.

Soetaert, K. \& VInCX, M. (1988). Spirobolbolaimus bathyalis, gen. nov., sp. nov. (Nematoda, Microlaimidae) from the Mediterranean (Calvi). Hydrobiologia 164, 33-38.

Stewart, A.C. \& Nicholas, W.L. (1987). Acanthomicrolaimus jenseni n. g., n. sp. (Nematoda: Microlaimidae) from marine sand. Cahiers de Biologie Marine 28, 91-96.

TCHesunov, A.V. (1990). New taxa of marine free-living nematodes of the family Xyalidae Chitwood, 1951 (Nematoda, Chromadoria, Monhysterida) from the White Sea. In: Gagarin, V.G. (Ed.). Fauna, biology and systematics of freeliving lower worms. Rybinsk, Russia, Institute of Inland Water Biology, Academy of Sciences of the USSR, Proceedings Issue 64, pp. 101-117.

Turpeenniemi, Nasira, K. \& Maqbool, M.A. (2001). A new genus, five new and five known species of freeliving marine nematodes (Nematoda: Monhysterida; Chromadorida) from Arabian Sea of Pakistan. Pakistan Journal of Nematology 19, 1-31.

VINCX, M. (1986). Free-living marine nematodes from the Southern Bight of the North Sea: 1. Notes on species of the genera Gonionchus Cobb, 1920, Neochromadora Micoletzky, 1924 and Sabatieria Rouville, 1903. Hydrobiologia 140, 255-286. 